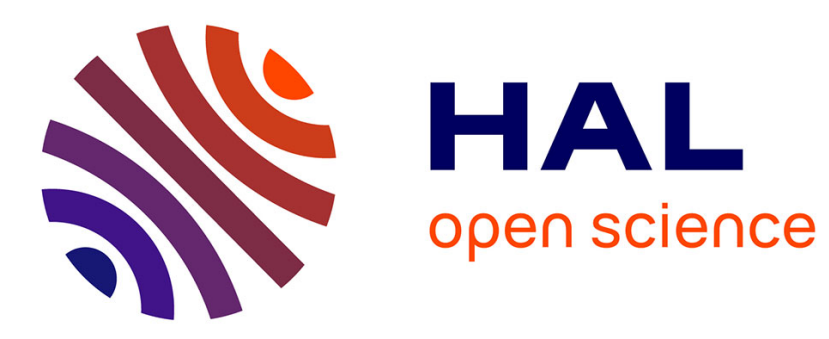

\title{
Characterisation of rosette formation in an aluminium-silicon alloy
}

Deni Ferdian, Yannick Thébault, Alexandre Freulon, Jacques Lacaze

\section{To cite this version:}

Deni Ferdian, Yannick Thébault, Alexandre Freulon, Jacques Lacaze. Characterisation of rosette formation in an aluminium-silicon alloy. International Journal of Cast Metals Research, The, 2015, 28 (5), pp.290-294. 10.1179/1743133615Y.0000000014 . hal-01481000

\section{HAL Id: hal-01481000 \\ https://hal.science/hal-01481000}

Submitted on 2 Mar 2017

HAL is a multi-disciplinary open access archive for the deposit and dissemination of scientific research documents, whether they are published or not. The documents may come from teaching and research institutions in France or abroad, or from public or private research centers.
L'archive ouverte pluridisciplinaire HAL, est destinée au dépôt et à la diffusion de documents scientifiques de niveau recherche, publiés ou non, émanant des établissements d'enseignement et de recherche français ou étrangers, des laboratoires publics ou privés. 


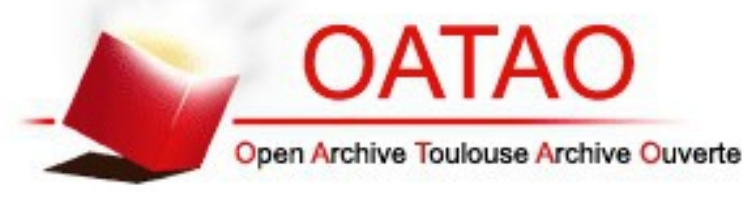

\section{Open Archive TOULOUSE Archive Ouverte (OATAO)}

OATAO is an open access repository that collects the work of Toulouse researchers and makes it freely available over the web where possible.

This is an author-deposited version published in : http://oatao.univ-toulouse.fr/ Eprints ID : 16718

To link to this article : DOI:10.1179/1743133615Y.0000000014

URL :http://dx.doi.org/10.1179/1743133615Y.0000000014

To cite this version : Ferdian, Deni and Thébault, Yannick and Freulon, Alexandre and Lacaze, Jacques Characterisation of rosette formation in an aluminium-silicon alloy. (2015) International Journal of Cast Metals Research, The, vol. 28 (n 5). pp. 290-294. ISSN 13640461

Any correspondence concerning this service should be sent to the repository administrator: staff-oatao@listes-diff.inp-toulouse.fr 


\title{
Characterisation of rosette formation in an aluminium - silicon alloy
}

\author{
D. Ferdian ${ }^{* 1,2}$, Y. Thebault ${ }^{1}$, A. Freulon ${ }^{1}$ and J. Lacaze ${ }^{1}$
}

\begin{abstract}
Differential thermal analysis has been used to investigate the effect of cooling rate on rosette formation during solidification of a synthetic Al-Fe-Si alloy. Rosettes can be characterised as a very fine multiphase structure within more or less convex areas dispersed in the matrix. Their formation during solidification is related with liquid entrapment and high solidification undercooling associated with the need of independent nucleation events of second phases. It is here shown that their density and internal coarseness depend on cooling rate. Further, metallographic observation of rosettes in contact with large precipitate of $\beta-\mathrm{Al}_{9} \mathrm{Fe}_{2} \mathrm{Si}_{2}$ phase allowed to conclude that this latter phase does not help silicon nucleation.
\end{abstract}

Keywords: Al-Si alloys, Differential thermal analysis, Solidification sequence, Eutectic undercooling, Rosette

\section{Introduction}

A special microstructure feature of aluminium alloys, called rosettes, has been reported since long. ${ }^{1}$ As illustrated in Fig. 1, rosettes consist in convex areas with a very fine multiphase microstructure. The characteristic size of the precipitates in these areas is much smaller than that of interdendritic precipitates in a given sample. Davis ${ }^{1}$ reported rosette appearance as a result of partial alloy remelting, e.g. because of burning in case of heat treatment or in the clad material during brazing. Such partial remelting rosettes have also been observed in laboratory studies of various aluminium alloys. ${ }^{2,3} \mathrm{Kim}$ and Cantor ${ }^{2}$ suggested that the convex shape of rosettes results from minimisation by surface tension of the area between the liquid and the surrounding matrix.

In addition to the case of partial remelting, rosettes have been reported also for as solidified aluminium alloys with either dendritic ${ }^{4,5}$ or cellular columnar, microstructure. It has been proposed that rosettes result from isolated liquid pools entrapped within the growing solid, between dendrite arms in the former case ${ }^{4}$ or because of tip splitting of the cellular structure in the latter case. ${ }^{7}$ According to Lacaze et al., ${ }^{4}$ the fine microstructure results from the fact that these isolated liquid pools may undergo high undercooling before nucleation of new phases allows them to complete solidification. Undercoolings of $20-40 \mathrm{~K}$ of the final eutectic have been effectively observed in the case of a 2024 alloy that supports this hypothesis. ${ }^{4}$

The purpose of the present work was, first, to investigate the effect of cooling rate on the formation of solidification rosettes in the case of an $\mathrm{Al}-\mathrm{Si}$

${ }^{1}$ CIRIMAT, Université de Toulouse, ENSIACET, BP 44362, Toulouse, Cedex 4 31030, France

${ }^{2}$ Department of Metallurgy and Materials, Universitas Indonesia, Kampus Baru UI, Depok 16424, Indonesia

*Corresponding author, email deni@metal.ui.ac.id synthetic alloy. From this investigation, some other interesting features were observed that are detailed.

\section{Experimental}

An Al-6.5Si-1Fe (in wt-\%) synthetic alloy was prepared by Hydro Aluminium Deutschland $\mathrm{GmBH}$ from high purity metals, from which rods of $10 \mathrm{~mm}$ diameter were obtained by hot extrusion. Samples were then machined into rods of $\sim 3.9 \mathrm{~mm}$ diameter and $5 \mathrm{~mm}$ height for differential thermal analysis (DTA) using a SETARAMSETSYS apparatus. All DTA experiments were carried out under a low argon flow and consisted in heating at $10^{\circ} \mathrm{C} \mathrm{min}^{-1}$, holding at $650^{\circ} \mathrm{C}$ for $10 \mathrm{~min}$ and finally cooling to room temperature at a fixed rate $(0.02,0.05$, $0.1,0.2,1,5,10$ and $40^{\circ} \mathrm{C} \mathrm{min}{ }^{-1}$ ).

Differential thermal analysis samples were then mounted and prepared for metallographic examination by grinding with abrasive papers of decreasing size and finally polishing with a $0.05 \mu \mathrm{m}$ Struers OP-S solution. Characterisation of the rosettes was made using optical microscopy (Nikon Eclipse MA 200) and scanning electron microscopy (LEO $435 \mathrm{VP}$ ) of unetched samples. Chemical analyses have been performed by energy dispersive spectrometry on the SEM and by wavelength dispersive spectrometry with a microprobe (CAMECA SX 50).

\section{Results and discussion}

Upon cooling from the liquid state, solidification of the investigated alloy starts with primary deposition of (Al), followed by a eutectic reaction where (Al) and $\beta-\mathrm{Al}_{9} \mathrm{Fe}_{2} \mathrm{Si}_{2}$ phase deposits, and completes at the invariant (Al)- $\beta$-Si three-phase ternary eutectic. ${ }^{8,9}$ Beta and silicon precipitates appear light and dark grey respectively under optical microscopy as in Fig. 1.

The number of rosettes was evaluated in an area of $9.65 \mathrm{~mm}^{2}$ of the axial metallographic section of each DTA sample. As seen in Table 1 , no rosette could be 


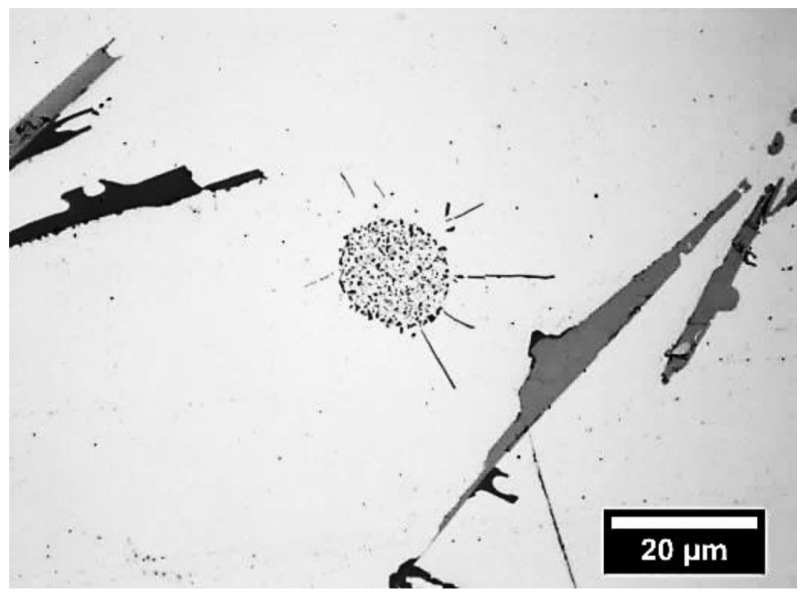

1 Micrograph of round rosette in Al-1Fe-6.5Si (wt-\%) alloy solidified at cooling rate of $5^{\circ} \mathrm{C} \mathrm{min}^{-1}$ : bright matrix is (Al) phase, and light and dark grey precipitates are beta and silicon precipitates respectively observed for the two lowest cooling rates, while their number then increased with cooling rate. Figure 2 illustrates the microstructure change with cooling rate: rosettes are smaller in size and show a finer internal structure as the cooling rate increases. These observations parallel the expected refinement of the dendritic structure of the $(\mathrm{Al})$ primary phase as the cooling rate is increased. This supports the previous suggestion that rosettes result from pools of liquid entrapped between dendrite arms. Further, entrapment of liquid between dendrite arms has been observed recently by in situ tomography. ${ }^{10}$

At any cooling rate, rosettes show a much finer microstructure than the surrounding eutectic precipitates, which have developed in interdendritic areas. However, at decreasing cooling rate, this structure coarsens significantly, and this may have two reasons: first, the undercooling for solidification of rosettes decreases with the cooling rate, possibly because there is more time for nucleation at given temperature, and second, solid state

Table 1 Number of rosettes observed in area of $9.65 \mathrm{~mm}^{2}$ of DTA samples

\begin{tabular}{llllllllll}
\hline & & \multicolumn{9}{c}{ Cooling rates ${ }^{\circ} \mathrm{C}$ min $^{-1}$} & & & \\
& 0.02 & 0.05 & 0.1 & 0.2 & 1 & 2 & 5 & 10 & 40 \\
\hline Number of rosettes & $\ldots$ & $\ldots$ & 1 & 2 & 1 & 3 & 6 & 7 & 24 \\
\hline
\end{tabular}
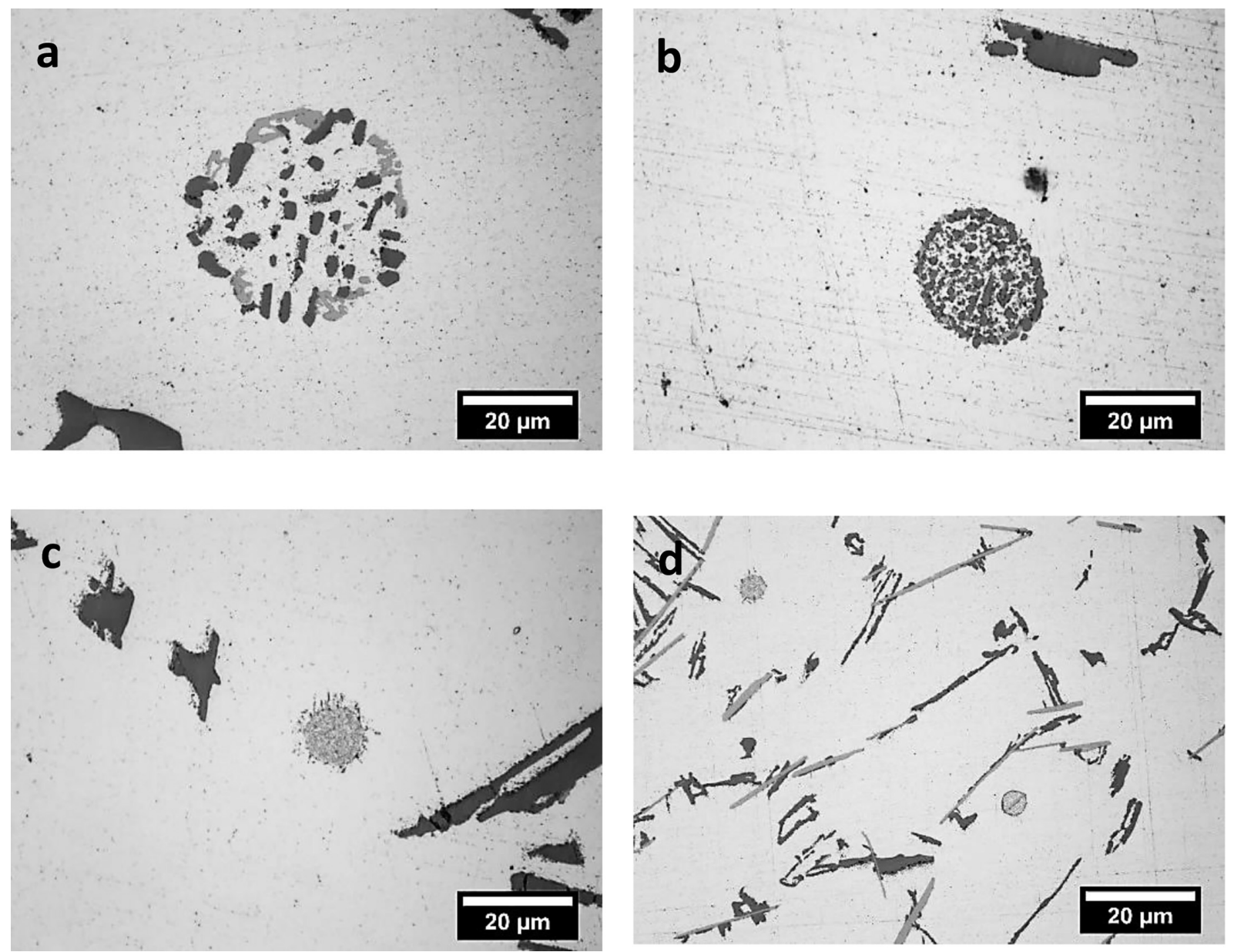

a $0.2^{\circ} \mathrm{C} \min ^{-1} ; b 1^{\circ} \mathrm{C} \min ^{-1} ; c 10^{\circ} \mathrm{C} \min ^{-1} ; d 40^{\circ} \mathrm{C} \min ^{-1}$

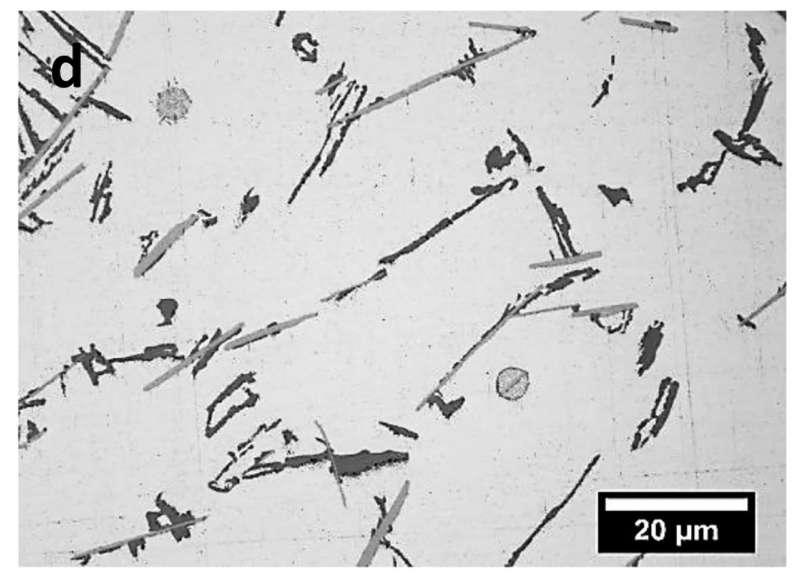

2 Micrographs of rosettes taken from samples cooled at different cooling rates 
coarsening is more and more efficient as the cooling rate decreases. Contrary to previous experiments on 2024 alloys,${ }^{4}$ the DTA traces recorded during the present study did not show any thermal arrest that could be related to solidification of undercooled liquid pockets. Thus, there is no clue from the present series of experiments to decide which one of the two above phenomena determines the internal coarseness of the rosettes' microstructure.

In Fig. $2 a$, the microstructure clearly appears to consist in three different phases. There is no doubt that the light phase is (Al) grown from the surrounding matrix and that the dark phase is silicon. The third phase should be an iron bearing phase to ensure consumption of iron rejected by both (Al) and silicon when the droplet solidifies, and such precipitate(s) should be present in every rosette.

Systematic investigation by optical microscopy of the presence of iron bearing phase in the rosettes appeared less and less easy as the microstructure was refined with increased cooling rate. Thus, SEM in backscattered electron imaging mode was used as illustrated in Fig. 3. The first rosette seen by optical microscopy in Fig. $3 a$ shows iron rich precipitates in bright contrast when observed in the SEM (Fig. 3b). These precipitates delineate some kind of elongated cells that are certainly two-phase (Al)-Si. Such a distribution would suggest multiple nucleation of the iron rich phase, which seems unlikely. An explanation to this may be given by the second rosette (lower row, Fig. $3 c$ ) for which the SEM image (Fig. 3d) shows a very fine dendritic iron rich precipitate that is revealed by backscattered electrons. One can imagine that any other section of this latter rosette would have appeared as in Fig. $2 b$.
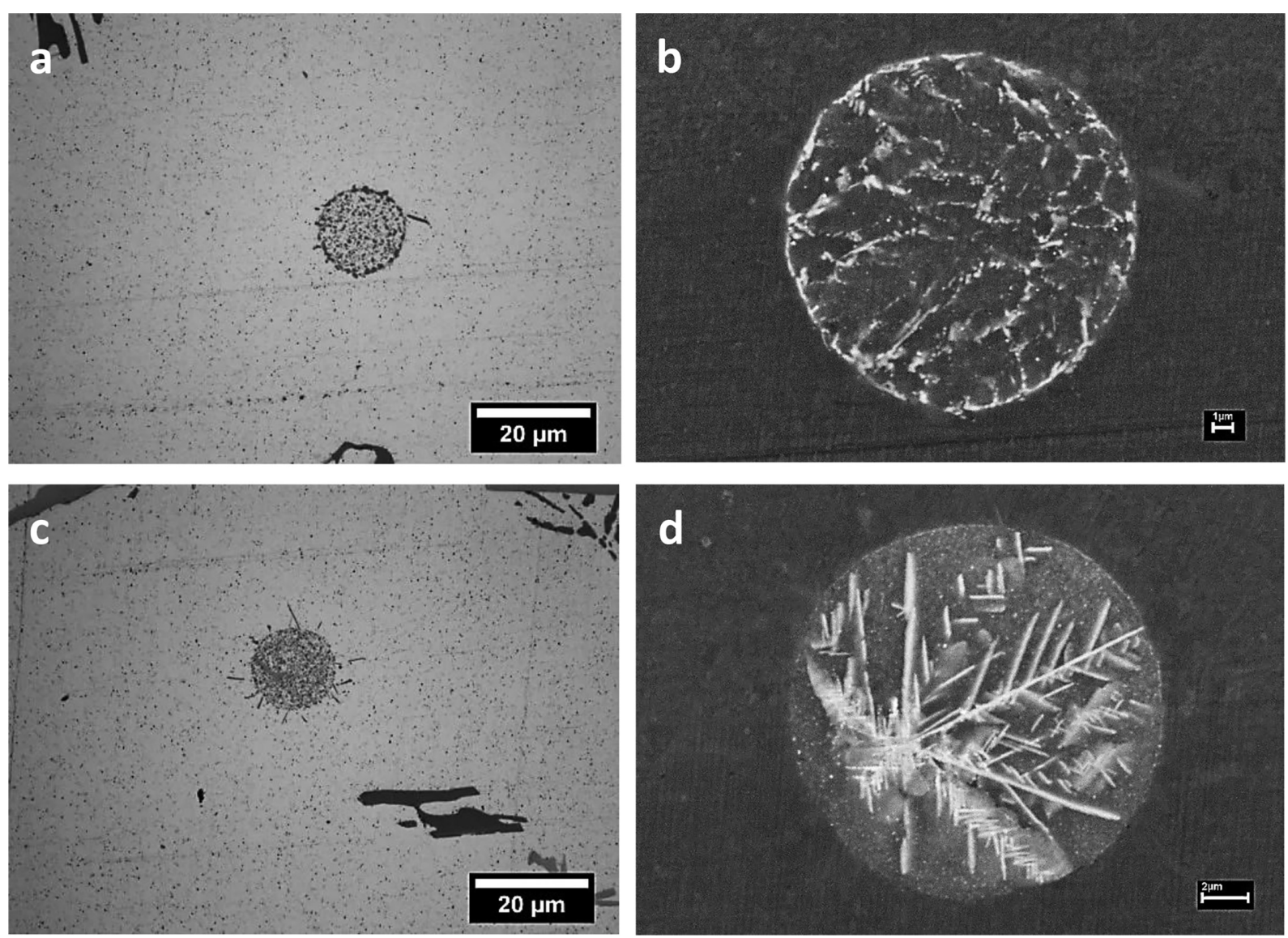

3 Micrographs of isolated rosettes obtained by optical microscopy ( $a$ and $c$ ) and in backscattered mode in SEM (b and d); sample cooled at $5^{\circ} \mathrm{C} \min ^{-1}$
In some cases, a plate-like precipitate with a size corresponding to the interdendritic eutectic precipitates was found in contact with a rosette as illustrated in Fig. 4. Owing to their size, it was easy to check by microanalysis that these precipitates consist in beta phase. ${ }^{11}$ Further, the size of these precipitates shows that they appeared during the normal eutectic (Al)- $\beta$, before the final eutectic where silicon is expected to precipitate together with $(\mathrm{Al})$ and beta phase. The presence of a large beta plate in contact with a rosette is a definite proof that beta phase does not act as nucleation site for eutectic silicon. This result is in agreement with previous conclusion by $\mathrm{Lu}$ and Dahle $\mathrm{P}^{12}$ and Liang and Schmid-Fetzer ${ }^{13}$ and contradicts other works. ${ }^{14-16}$

As carried out previously, ${ }^{4}$ an attempt was made to evaluate the average chemical composition of rosettes by electron probe microanalysis. Analyses were conducted on which were spotted ( $1 \mu \mathrm{m}$ in diameter) in selected zones and line scan across the rosettes as schematically seen in Fig. 5. Line scans were performed by acquiring data every $2-3 \mu \mathrm{m}$ across the middle section of the rosettes. Electron probe microanalyses showed the total of element contents to range between 89 and $96 \%$. Such a difference to the expected $100 \%$ is probably because rosettes are multiphase. $^{5,17}$

Chemical analysis of the spot zones from the two rosettes after normalising to $100 \%$ showed average silicon contents of 26.1 and $30.5 \mathrm{wt}-\%$ with the corresponding average iron contents of 6.7 and $2.5 \mathrm{wt}-\%$. Low level impurities were found to accumulate also, with small traces of $\mathrm{Ca}, \mathrm{Ti}$ and Mn sometimes appearing. The various zone measurements two rosettes with two types of measurement methods, 


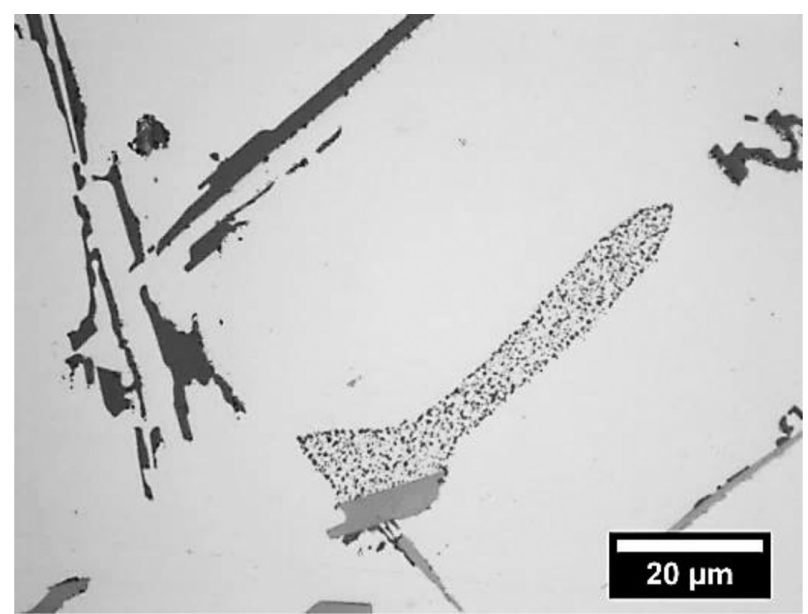

4 Rosette in contact with large plate-like precipitate of beta phase (light grey contrast); sample cooled at $40^{\circ} \mathrm{C} \mathrm{min}-1$
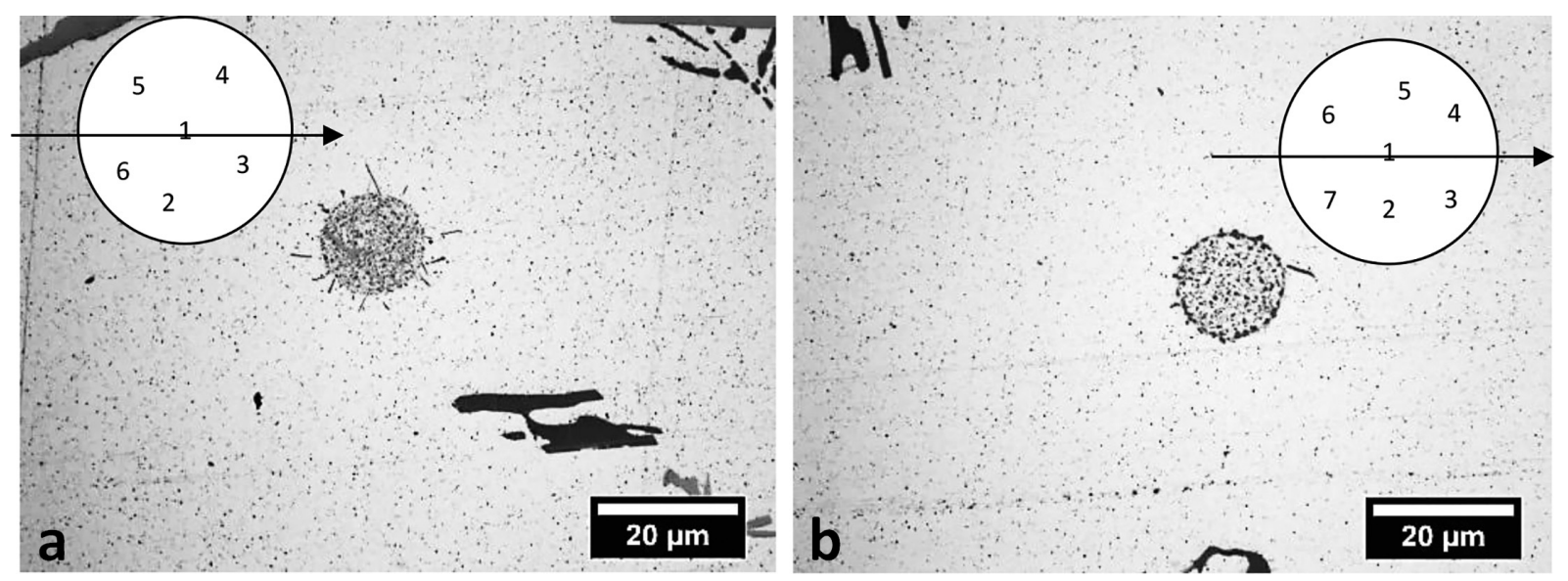

a rosette $1 ; b$ rosette 2

5 Electron probe microanalysis test locations of two rosettes taken from DTA sample with cooling rate of $5^{\circ} \mathrm{C} \mathrm{min}{ }^{-1}$; in superimposed schematics, numbers refer to so called spot counting in selected zones and lines illustrate scans

are plotted with solid symbols in Fig. 6, which represents the $\mathrm{Al}$ rich part of the liquidus projection of the $\mathrm{Al}-\mathrm{Fe}-\mathrm{Si}$ system calculated with the databank TCAL-2. ${ }^{18}$ Line scan values are plotted with open symbols in Fig. 6. They show fluctuations in silicon and iron measurements that are slightly higher than those obtained with zone analysis because the density of silicon precipitates was generally higher at the outer boundary of the rosettes. This latter observation is associated with solid state precipitation of silicon during cooling after solidification and leads also to the fine and often straight precipitates radiating from the rosettes in the ( $\mathrm{Al}$ ) matrix (as observed in Figs. 1, 3 and 5).

It is seen that the rosettes' compositions fall far away from the eutectic lines involving (Al). During solidification, growth of the (Al) primary phase around the entrapped liquid was continuous so that the liquid got enriched in solutes ( $\mathrm{Si}$ and $\mathrm{Fe}$ ) until nucleation of second phases occurred. In interdendritic areas, eutectic beta and silicon phases grow with low undercooling because each phase is interconnected so that one single nucleation event is sufficient. On the contrary, nucleation has to proceed in each liquid entrapped pool, and this leads to significant undercooling of the liquid with the associated very fine structure of the rosettes when they solidify. In some cases, nucleation of silicon only was necessary (Fig. 4), while in other cases, nucleation of both silicon and an iron bearing phase had to proceed (Fig. 3).

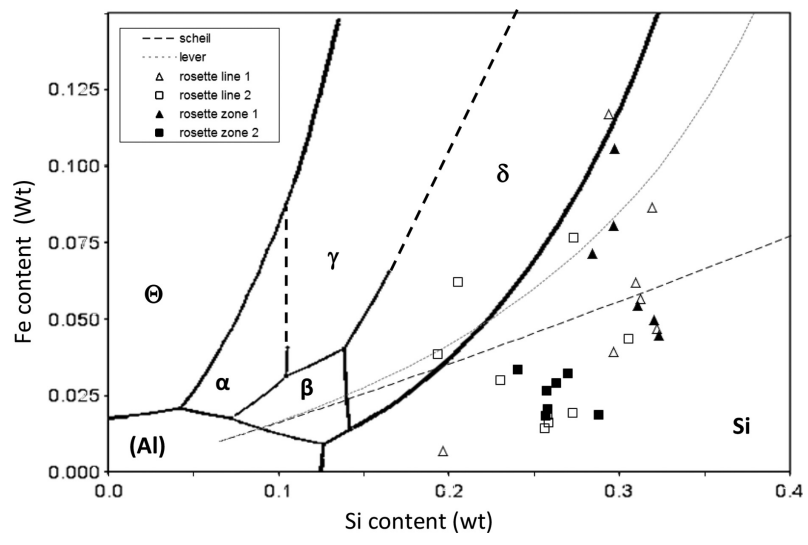

6 Electron probe microanalysis results of rosette compositions superimposed on $\mathrm{Al}$ corner of $\mathrm{Al}-\mathrm{Fe}-\mathrm{Si}$ liquidus projection $\left(\Theta-\mathrm{Al}_{13} \mathrm{Fe}_{4}, \alpha-\mathrm{Al}_{8} \mathrm{Fe}_{2} \mathrm{Si}, \beta-\mathrm{Al}_{9} \mathrm{Fe}_{2} \mathrm{Si}_{2}, \gamma-\mathrm{Al}_{3} \mathrm{FeSi}\right.$, $\delta$ - $\mathrm{Al}_{3} \mathrm{FeSi}_{2}$ ); open and solid symbols relate to line scan and spot zone measurements respectively 
The solidification paths of (Al) phase following the lever rule and the Scheil's model have been calculated assuming no second phase precipitation. They are plotted in Fig. 6 where it is seen that they run through the cloud of measured compositions of the rosettes. This sustains the above schematic. The calculated liquidus temperature corresponding to $30.5 \mathrm{wt}-\% \mathrm{Si}$ and $6.7 \mathrm{wt}-$ $\% \mathrm{Fe}$ is $438^{\circ} \mathrm{C}$ and that corresponding to $26.1 \mathrm{wt}-\% \mathrm{Si}$ and $2.5 \mathrm{wt}-\% \mathrm{Fe}$ is $479^{\circ} \mathrm{C}$. This would mean an undercooling of 136 and $95^{\circ} \mathrm{C}$ with respect to the invariant ternary eutectic at $574^{\circ} \mathrm{C}$.

The degree of undercooling of eutectic silicon can also be related to the silicon interlamellar spacing. Some of the studies on this relationship can be seen in the works by Steen and Hellawell, ${ }^{19}$ Hogan and Song, ${ }^{20}$ Glenister and Elliott ${ }^{21}$ and Gunduz et al. ${ }^{22}$ It is here assumed that the growth of highly undercooled (Al)-Si eutectic is similar to that of the modified (Al)-Si eutectic, so that data from Hogan and Song ${ }^{20}$ can be used. The eutectic silicon spacing within the rosettes formed at a cooling rate of $5^{\circ} \mathrm{C} \mathrm{min}{ }^{-1}$ was in the range of $0.35-0.5 \mu \mathrm{m}$. According to data from Hogan and Song, ${ }^{20}$ these values would correspond to undercooling in between 90 and $140^{\circ} \mathrm{C}$, which are similar to those evaluated on the basis of composition.

\section{Conclusions}

Formation of rosettes in as solidified aluminium alloys is related to liquid entrapment within the primary (Al) phase, which then undergoes large undercoolings for second phase(s) nucleation before solidification completion. This is sustained by their very fine microstructure and by composition measurements. The sensitivity to cooling rate of the characteristic size of the multiphase microstructure of rosettes should be further investigated to determine if it depends on nucleation undercooling or on solid state coarsening. However, such a study should be performed on another alloy for which DTA would show thermal arrest on rosette solidification. An interesting outcome of the present study is the direct proof that $\beta-\mathrm{Al}_{9} \mathrm{Fe}_{2} \mathrm{Si}_{2}$ phase does not help nucleation of eutectic silicon in $\mathrm{Al}-\mathrm{Si}$ alloys.

\section{Acknowledgements}

Financial support from the European Space Agency (contract no. 4200014347) through the MICAST program was greatly appreciated. Thanks are due to S. Gouy and P. de Parseval (UMS Castaing, Université de Toulouse) for electron probe microanalysis measurements.

\section{References}

1. J.R. Davis, Aluminum and aluminum alloys, ASM international, 1993

2. W.T. Kim and B.Cantor, Heterogeneous nucleation of $\mathrm{Al} 2 \mathrm{Cu}$ in $\mathrm{Al}-\mathrm{Cu}$ eutectic liquid droplets embedded in an Al matrix, Acta Metall. Mat., 42, 9 (1994), 3045-3053.

3. J.H. Li, M.Z. Zarif, M. Albu, B.J. McKay, F. Hofer, P. Schumacher, Nucleation kinetics of entrained eutectic $\mathrm{Si}$ in $\mathrm{Al}-5 \mathrm{Si}$ alloys, Acta Materialia, 72, (2014), 80-98.

4. J. Lacaze, G. Lesoult, I. Ansara, Rosettes in Al-Cu-Mg-Si Aluminium Alloys, Materials Science Forum, 217-222, (1996), 171-176.

5. S. Ahrweiler, L. Ratke, J. Lacaze, Microsegregation and microstructural features of directionally solidified AlSi and AlSiMg alloys, Advanced Engineering Materials, 5, (2003) 17-23.

6. P. Liu, T. Thorvaldsson, G. Dunlop, Formation of intermetallic compounds during solidification of dilute Al-Fe-Si alloys, Material Sci Tech, 1986, 2, 1009

7. D.T.L. Alexander and A.L Greer, Formation of eutectic intermetallic rosettes by entrapment of liquid droplets during cellular columnar growth, Acta Materialia, 52, (2004), 5853-5861.

8. D. Ferdian, B. Suharno, B. Duployer, C. Tenailleau, L. Salvo, J. Lacaze, Differential Thermal Analysis Assessment of Beta Phase Precipitation in Al-6.5Si-1Fe Alloy, Trans. Indian Ins. Met., (2012), 65, 821-825.

9. D. Ferdian, C. Josse, P. Nguyen, N. Gey, N. Ratel-Ramond, P. de Parseval, Y. Thebault, B. Malard, J. Lacaze, L. Salvo, Chinese Script vs PlateLike Precipitation of Beta- $\mathrm{Al}_{9} \mathrm{Fe}_{2} \mathrm{Si}_{2}$ Phase in an Al-6.5Si-1Fe Alloy, Metallurgical and Materials Transactions A, (2015), 46A, 2814-2818.

10. S. Terzi, L. Salvo, M. Suéry, A.K. Dahle, E. Boller, Coarsening mechanisms in a dendritic $\mathrm{Al}-10 \% \mathrm{Cu}$ alloy, Acta Materialia, 58, (2010), 20-30.

11. D. Ferdian, Effet de la vitesse de refroidissement sur la taille des grains, la modification eutectique et la précipitation d'intermétalliques riches en fer dans des alliages Al-Si hypoeutectiques. (Cooling rate effects on grain size, eutectic modification and Fe-bearing intermetallic precipitation in hypoeutectic Al-Si alloys.), Université de Toulouse, INPT, PhD thesis, 2014, http://ethesis.inp-toulouse.fr/archive/00002786/01/ferdian.pdf (Extended abstract in French, text in English)

12. L. Lu, A.K. Dahle, Iron-rich intermetallic phases and their role in casting defect formation in hypoeutectic $\mathrm{Al}-\mathrm{Si}$ alloys, Metallurgical and Materials Transactions A, 36, (2005), 819-835.

13. S-M. Liang, R. Schmid-Fetzer, Nucleants of Eutectic Silicon in Al-Si Hypoeutectic Alloys: $\beta$-(Al, Fe, Si) or AlP Phase, Metallurgical and Materials Transactions A, 2014, 45A, 5308-5312.

14. J.A. Taylor, G.B. Schaffer, D.H. StJohn, The role of iron in the formation of porosity in Al-Si-Cu-based casting alloys: Part III. A microstructural model, Metallurgical and Materials Transactions A, 30, (1999), 16571662.

15. L. Liu, A.M. Samuel, F.H. Samuel, H.W. Doty, and S. Valtierra, Role of iron in relation to silicon modification in Sr-treated 319 and 356 alloys, Int. J. Cast Met. Res, 16, (2003), 397-408.

16. S. Shankar, Y.W. Riddle, M.M. Makhlouf, Nucleation mechanism of the eutectic phases in aluminum-silicon hypoeutectic alloys, Acta Mater, 2004, 52, 4447-4460

17. J. Lacaze, P. Benigni, A. Howe, Some Issues Concerning Experiments and Models for Alloy Microsegregation, Advanced Engineering Materials, 5, (2003) 37-46.

18. TCAL2 - TCS Al-based alloy Database, Version 2.1.1, www.thermocalc. com/media/11295/tcal2-1-1 extended info.pdf

19. H.A. Steen, A. Hellawell, The growth of eutectic silicon-contributions to undercooling, Acta Metallurgica, 1975, 23, 529-535.

20. L.M. Hogan, H. Song, Interparticle spacings and undercoolings in Al-Si eutectic microstructures, Metallurgical Transaction, 1987, 18A, 707-713.

21. S.M.D. Glenister, R. Elliott, Strontium modification of AI- $12.7 \mathrm{wt}-\% \mathrm{Si}$ alloys, Metal Sci J, 1981, 15, 181.

22. M. Gunduz, H. Kaya, E. Cadirli, A. Ozmen, Interflake spacings and undercoolings in Al-Si irregular eutectic alloy, Mat Sci Eng A, 2004, 369, 215-229. 